Idan Alaa Fadhil I

\title{
DEVELOPMENT OF THE COMBINED HARDENING TECHNOLOGY OF OBTAINING SOLID COATING ON THE SURFACE OF STEEL PRODUCTS
}

Досліджено прочес отримання твердого покриття на поверхні сталевих виробів методом комбінованої локальної змічнюючої технології з інтенсифікацією процесу борування. Встановлено вплив попередньої лазерної обробки сталі на збільшення глибини зміцненого шару в 2,7-5,5 рази. Визначено, що комбінована локальна змічнююча технологія сталі сприяє збільшенню поверхневої твердості до 22 ГПа.

Ключові слова: лазерна обробка, інтенсифікація прочесу борування, глибина змічненого шару, мікротвердість.

\section{Introduction}

Surface destruction of machine parts leads to failure of machine mechanisms [1]. The reasons for this are wear of machine parts during operation. A particularly negative effect on the surface of products has an abrasive wear [2]. The reasons for this are friction processes of more solid materials or individual particles on the surface of the machine parts. Predominantly majority of machine parts used on real objects are ferrous metals, namely steel [3]. Substitution of steels with poor mechanical performance properties for more expensive alloy steels with good properties isn't economically feasible and isn't always required the high values of strength and hardness throughout the machine part, but rather only on its surface. In this regard, researches to finding ways to improve the technological processes for durability improvement of machine parts are relevant. In this case surface hardening of steel products is interest. It is necessary to take into account the features of methods to increase hardness and strength of the surface layer of steel and the peculiarities of the forming hardened layer on the carbon and alloy steels for development of appropriate technological solutions.

\section{The object of research and its technological audit}

The object of research is a process for obtaining a solid coating on the surface of steel products. One of the most problematic features of this process is the considerable duration of the known methods and the need for a method of local hardening of the surface of machine parts.

To identify the features of this process from the perspective of the local surface hardening, technology audit is carried out aiming at the determination of the following process parameters: laser beam velocity, thickness of the hardened surface layer.

Technological scheme of the process is shown in Fig. 1.

Laser treatment has been undertaken using machine «Лaтус-31» (Russia), a main view of which is shown in Fig. 2 [4], according to the following modes:

- Emission power - 1,0 $\pm 0,1 \mathrm{~kW}$;
- Diameter of the beam focusing area $-5 \mathrm{~mm}$;

- Laser beam velocity - 0,5-1,5 m/min.

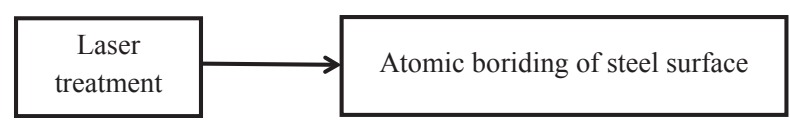

Fig. 1. Technological scheme of the local surface hardening of machine parts

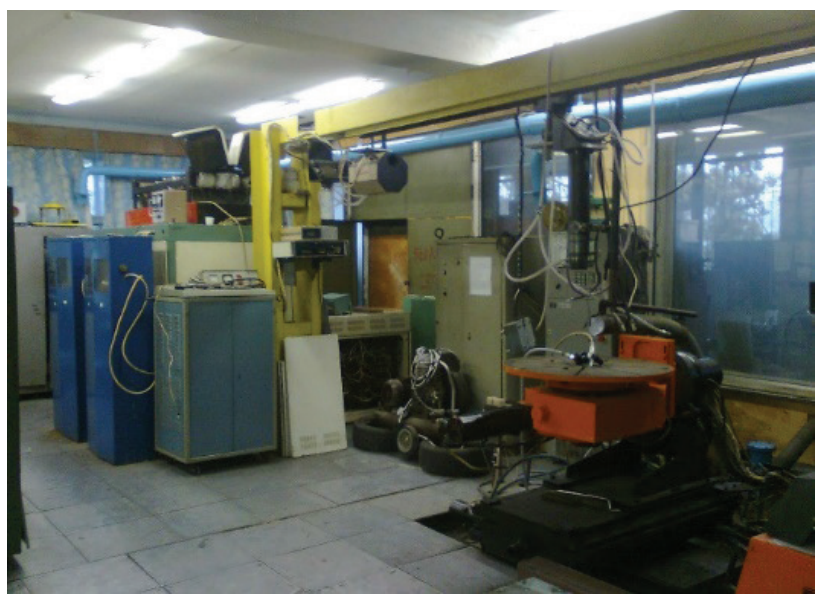

Fig. 2. The main view of technological complex «Латус-31»

This machine operates as follows. Emitter with longitudinal fast pumping and convective mixture cooling, equipped with a powerful high-voltage DC source. Emission power is continuously monitored by special continuous measurer operating by a tap of emission part (10\%) from the primary beam (2\% accuracy).

The focus of the laser emission is carried out using the lens objective. The focusing elements are plano-convex spherical lens with a focal length of $300 \mathrm{~mm}$. Change of the focus spot size is carried out by adjusting the distance from the focusing element to the surface in the range of $d_{0}=2,0-7,0$ with an accuracy of $\pm 0,05 \mathrm{~mm}$.

Measurement of the focus spot diameter is held by the emission intensity distribution curve in the cross section at $I_{\max } / e^{2}$ distance from the main plane. The intensity 
distribution in the cross section of the focused beam is performed by scanning method with a special pyroelectric analyzer.

Atomic boriding of steel surface is carried out by boriding method in the powder medium that contains atomic boron and activators. Boriding is carried out in a chamber furnace.

Traditional boriding methods demand the special equipment for realization and their duration is up to 8 hours. Therefore, the main direction of improvement of the technological implementation of surface hardening is an intensification of boriding processes. The most important should be considered a necessity to create the deformed structure of the surface layer and the use of new saturating medium. This will in practical conditions greatly accelerate local surface hardening process, which, in turn, leads to considerable energy savings.

\section{The aim and objectives of research}

The aim of research is improvement of technological schemes of local surface hardening of machine parts to ensure high performance properties of the surface layer of steel.

To achieve this aim it is necessary to solve the following tasks:

1. Intensify boriding process by preliminary laser treatment of the surface of steel products.

2. Study an influence of preliminary laser treatment of the steel on change of the depth of the hardened layer.

3. Study the effect of preliminary laser treatment of steel on change of the surface hardness values.

\section{Research of existing solutions of the problem}

Among the main directions to eliminate the problem of failure of machines and mechanisms sufficiently effective methods of surface hardening of steels are:

- Innovative methods of chemical and thermal treatment [5-9];

- Laser treatment [10-12];

- Combined methods of surface hardening [13-15].

In particular, the article [5] is devoted to the hardening of the surface layers of steel $38 \mathrm{Cr} 2 \mathrm{MoAl}$ by combination of chemical and thermal treatment. It is shown that surface double-layer hardening of steel with sequential saturation with atomic carbon) and boron allows to form a boride layer with transition zone. The obtaining transition zone can improve operational properties of machine parts and tools by micro-friability reduction of diffusion layer. However, this process is limited by temperature regimes and the inability of local hardening that do not allow sufficiently specific to provide performance characteristics with minimal power consumption. A similar circumstance is mentioned in [6-9], which concluded a necessity of compromise solutions that improve the durability of machine parts without the use of complicated special equipment. The authors have shown that this approach provides a suitable practical result, but naturally restriction on its use is non-locality of the hardening.

An alternative solution is given in [10-12], but it doesn't suggest the combined treatment, and hardening is realized only by laser treatment that does not always provide sufficient operational properties of machine parts.
Specific development of this approach can be found in [13-15], which has, however, a number of significant disadvantages that are shown below.

- Do not allow to obtain the wear layer on the steel product, and it is only suitable for metallic parts made of soft metals or alloys. In addition, an implementation of surface plastic deformation by roller due to discrete cellular-reticulate pattern complicates and lengthens the process time, which leads to additional consumption of electricity [13].

- Do not allow to obtain a product with high contact and fatigue resistance of the surface in a highly triboforce load due to insufficient thickness of the cold-hardened base layer, distribution of stresses in it; it does not allow to obtain wear-resistant layer of sufficient thickness on steel products. In addition, preliminary treatment of product surface by intensive plastic deformation method using ultrasonic impact treatment method leads to additional consumption of electricity and the need for additional expensive equipment [14]. - High boriding temperature $940{ }^{\circ} \mathrm{C}$ and duration of the process up to 3 hours increase energy consumption, and the resulting coating has an insufficient thickness up to $110-115 \mathrm{~mm}$ for steel $\mathrm{C}_{\mathrm{T}} 3$ and $90-95$ microns for steel 45. As a result, high performance properties of products aren't provided [15].

Thus, the results suggest that creation of innovative technology of local surface hardening of machine parts to ensure high performance properties of the surface layer of steel is relevant. Selection of the most appropriate technical solution should be based on an intensification of boriding process.

\section{Methods of research}

Experimental studies are carried out for samples of steel $38 \mathrm{Cr} 2 \mathrm{MoAl}$.

Input variables of the process are the laser beam velocity.

Output variables of the process - the thickness of the hardened layer is determined by the method of change of microhardness indicators from the sample surface to the core in a cross-section. Full description of the standard method can be found, for example, in [5, 8].

Boriding is carried out in powder medium with fine boron-contained substance and activators.

The effect of preliminary treatment and final laser boriding on the structure, thickness, phase composition, microhardness of the surface layers of samples is studied by the methods of metallographic analysis using metallographic МИМ-7 microscope with a digital unit, ДРОН-3, ПМТ-3 (Russia).

\section{Research results}

It is found that grinding of the grain structure of the surface layers of steel $38 \mathrm{Cr} 2 \mathrm{MoAl}$ takes place after the laser treatment. In this case, the thickness of the hardened layer ranges from 0,2 to $0,41 \mathrm{~mm}$ depending on the change of the laser beam velocity (between 1,5 and $0,5 \mathrm{~m} / \mathrm{min}$, respectively).

Subsequent boriding it possible to obtain a higher boride layer with a thickness of $0,140 \mathrm{~mm}$ and microhardness up to $22,5 \mathrm{GPa}$, compared with boriding without preliminary laser treatment providing a hardness of $20 \mathrm{GPa}$ and depth of the layer up to 0,073 . For further comparison capabilities 
boriding is conducted under the same conditions for the same duration of 1 hour.

Such high rates of boride layer thickness and microhardness after combined treatment is explained by the facilitated diffusion of boron atoms and increase of its solubility by the formation of a defective metal structure after laser treatment (increased dislocation density, grain crushing and increase the length of their borders, producing ultrafine disoriented grains).

$\mathrm{X}$-ray phase analysis of investigated steels reveals the presence of borides and $\alpha$-Fe.

The offered application of boriding technology of steel products will allow to combine chemical and heat treatment with a heat treatment operation, which will increase the service life of equipment parts operating properties of the diffusion layers of tools, stamping and pressing equipment.

\section{SWOT analysis of research results}

Strengths. Strengths of this research are development of the combined hardening technologies of local hardening of the surface layers of steel machine parts. The proposed method of obtaining a hard coating on the surface of steel products provides the following advantages:

- Increase of the production rate of diffusion layers

by $2-3$ times;

- Improvement of performance properties of steel products;

- Significantly reduce of the process complexity with substantial energy savings by eliminating the need for additional costly thermal equipment;

- Possibility of boriding process in a conventional oxidizing atmosphere without special equipment, sealing and the use of protective atmospheres;

- Improvement of manufacturability and working conditions.

Weaknesses. Weaknesses of this research are related to the fact that this hardening is a local and intensification of boron saturation process occurs through the use of laser treatment in which it is necessary to take into account mainly laser beam velocity. This may lead to possible additional costs associated with the process providing by additional control and regulation systems.

Opportunities. Additional features that achieve the aim of research are to develop a wider range of combined technologies of the surface hardening of steels. At the same time due to the proposed technology of boriding intensification it is possible to solve the problem of compromise increase of productivity and quality of the surface layer of steel.

Threats. Threats in the implementation of the obtained results of the study are related to the following factors:

- Management of companies that are operated machine parts. Investment of additional funds in development of new alloys. The company's policy is to purchase finished products and unwillingness to develop their technologies.

- The market of modern engineering equipment offered by the world's leading companies. Long-term invest forecast can show that purchase of a new type of units can be more appropriate to modernization of physically obsolete.

Thus, SWOT analysis of research results allow to identify the main directions for successful achievement of aim of the research. Among them - development of innovative technologies of surface hardening with the use of combined methods of increase of operational properties of machine parts and service life in general.

\section{Conclusions}

1. Boriding process is intensified by preliminary laser treatment of the surface of steel products and the use of fine boron powder as a saturating medium for chemical and heat treatment.

2. The study of the effect of preliminary laser treatment of steel on change of the depth of the hardened layer shows that the laser treatment increases the hardened layer in 2,7-5,5 times depending on the rate of change of laser beam velocity.

3. It is shown that preliminary laser treatment of steel increases surface hardness after boriding steel by $2 \mathrm{GPa}$ in comparison with traditional boriding.

\section{References}

1. Hahn, D. W. Laser-Induced Breakdown Spectroscopy (LIBS), Part II: Review of Instrumental and Methodological Approaches to Material Analysis and Applications to Different Fields [Text] / D. W. Hahn, N. Omenetto // Applied Spectroscopy. - 2012. Vol. 66, № 4. - P. 347-419. doi:10.1366/11-06574

2. Fadhil, I. A. The innovative technology of high-speed nitriding steel [Text] / I. A. Fadhil, K. Kostyk, O. Akimov // Bulletin of the National Technical University «KhPI» Series: New solutions in modern technologies. - 2016. - № 42 (1214). P. 49-53. doi:10.20998/2413-4295.2016.42.08

3. Aqida, S. N. Thermal fatigue properties of laser treated steels [Text] / S. N. Aqida, F. Calosso, D. Brabazon, S. Naher, M. Rosso // International Journal of Material Forming. - 2010. Vol. 3, № S1. - P. 797-800. doi:10.1007/s12289-010-0890-1

4. Idan, A. F. I. The study of the influence of laser hardening conditions on the change in properties of steels [Text] / A. F. I. Idan, O. Akimov, L. Golovko, O. Goncharuk, K. Kostyk // Eastern-European Journal of Enterprise Technologies. - 2016. № $2 / 5$ (80). - P. 69-73. doi:10.15587/1729-4061.2016.65455

5. Kostyk, K. Development of the high-speed boriding technology of alloy steel [Text] / K. Kostyk // Eastern-European Journal of Enterprise Technologies. - 2015. - № 6/11 (78). P. 8-15. doi:10.15587/1729-4061.2015.55015

6. Kostyk, K. Double-layered surface hardening of steel in successive saturation of carbon and boron in powdered macro and nanoscale environments [Text] / K. Kostyk // Bulletin of the National Technical University «KhPI» Series: New solutions in modern technologies. - 2016. - № 42 (1214). - P. 54-63. doi:10.20998/2413-4295.2016.42.09

7. Dhafer, W. The choice of the optimal temperature and time parameters of gas nitriding of steel [Text] / W. Dhafer, V. Kostyk, K. Kostyk, A. Glotka, M. Chechel // Eastern-European Journal of Enterprise Technologies. - 2016. - № 3/5 (81). P. 44-50. doi:10.15587/1729-4061.2016.69809

8. Kostyk, K. Development of the high-speed boriding technology of alloy steel [Text] / K. Kostyk // Eastern-European Journal of Enterprise Technologies. - 2015. - № 6/11 (78). P. 8-15. doi:10.15587/1729-4061.2015.55015

9. Mohanad, M. Modeling of the case depth and surface hardness of steel during ion nitriding [Text] / M. Mohanad, V. Kostyk, D. Domin, K. Kostyk // Eastern-European Journal of Enterprise Technologies. - 2016. - № 2/5 (80). - P. 45-49. doi:10.15587/1729-4061.2016.65454

10. Lobankova, O. V. Influence of laser radiation on structure and properties of steel [Text] / O. V. Lobankova, I. Y. Zykov, A. G. Melnikov, S. B. Turanov // Advanced Materials, Structures and Mechanical Engineering: Proceedings of the international Conference on Advanced Materials, Structures and Mechanical Engineering, Incheon, South Korea, May 29-31, 2015. - CRC Press, 2016. - P. 75-78. doi:10.1201/b19693-16 
11. Fadhil I, I. A. The influence of pre-heat treatment and laser hardening on the steel structure formation [Text] / I. A. Fadhil I, O. Akimov, K. Kostyk, O. Goncharuk // Bulletin of the National Technical University «KhPI» Series: New solutions in modern technologies. - 2016. - № 18 (1190). - P. 66-73. doi:10.20998/2413-4295.2016.18.10

12. Okamuro, K. Laser fluence dependence of periodic grating structures formed on metal surfaces under femtosecond laser pulse irradiation [Text] / K. Okamuro, M. Hashida, Y. Miyasaka, Y. Ikuta, S. Tokita, S. Sakabe // Physical Review B. - 2010. Vol. 82, № 16. - P. 165417. doi:10.1103/physrevb.82.165417

13. Sposib otrymannia tverdoho pokryttia z pidvyshchenym oporom vtomnomu ruinuvanniu na poverkhni metalevoho vyrobu [Electronic resource]: Patent UA 98452 U, MPK C 23 C 14/00 / Kindrachuk M. V., Dukhota O. I., Kudrin A. P., Tisov O. V., Mikosianchyk O. O., Naumenko N. O. - № u201412654; filed 25.11.2014 published 27.04.2015, Bull. № 8. - Available at: \www/ URL: http://uapatents.com/6-98452-sposib-otrimannya-tverdogo-pokrittya-z-pidvishhenim-oporom-vtomnomu-rujjnuvannyuna-poverkhni-metalevogo-virobu.html

14. Method for producing of solid coating on surface of metalic article [Electronic resource]: Patent UA 75866 U, MPK C 23 C 14/00 Vasilev M. O., Panarin V. Ye., Sydorenko S. I., Voloshko S. M., Burmak A. P. - № u201208822; filed 17.07.2012; published 10.12.2012, Bull. № 23. - Available at: \www/URL: http:// uapatents.com/4-75866-sposib-otrimannya-tverdogo-pokrittyana-poverkhni-metalevogo-virobu.html
15. Sposob borirovaniia uglerodistoi stali [Electronic resource]: $\mathrm{Pa}$ tent RU 1617035 A1, MPK C23C 8/70, C23C 8/02 / Sizov I. G. Prusakov B. A., Novakova A. A., Kornilova A. A.; assignee: East Siberia State University of Technology and Management. № 2005123677/02; filed 25.07.2005; published 20.02.2007, Bull. № 5. - Available at: \www/URL: http://www.findpatent.ru/ patent/229/2293789.html

\section{РАЗРАБОТКА КОМБИНИРОВАННОЙ УПРОЧНЯЮЩЕЙ ТЕХНОЛОГИИ ЛОЛУЧЕНИЯ ТВЕРДОГО ЛОКРЫТИЯ НА ЛОВЕРХНОСТИ СТАЛЬНЫХ ИЗДЕЛИЙ}

Исследован процесс получения твердого покрытия на поверхности стальных изделий методом комбинированной локальной упрочняющей технологии с интенсификацией процесса борирования. Установлено влияние предварительной лазерной обработки стали на увеличение глубины упрочненного слоя в 2,7-5,5 раза. Определено, что комбинированная локальная упрочняющая технология стали способствует увеличению поверхностной твердости до 22 ГПа.

ключевые слова: лазерная обработка, интенсификация процесса борирования, глубина упрочненного слоя, микротвердость.

Idan Alaa Fadhil I, Postgraduate student, Department of Foundry Production, National Technical University «Kharkiv Polytechnic Institute»,Ukraine, e-mail: litvo11@kpi.kharkov.ua, ORCID: http:// orcid.org/0000-0001-9466-1157 